\title{
Wielician (Middle Badenian) foraminifers from the stratotype area - Wieliczka Salt Mine, Poland (Paratethys, Middle Miocene)
}

\author{
Małgorzata GONERA ${ }^{1, *}$, Janusz WIEWIÓRKA ${ }^{2}$, Kajetan D'OBYRN ${ }^{2}$ \\ and Krzysztof BUKOWSKI ${ }^{3}$
}

1 Polish Academy of Sciences, Institute of Nature Conservation, Al. A. Mickiewicza 33, 31-120 Kraków, Poland

2 Wieliczka Salt Mine, Park Kingi 5, 32-020 Wieliczka, Poland

3 AGH University of Science and Technology, Faculty of Geology, Geophysics and Environmental Protection, Al. A. Mickiewicza 30, 30-059 Kraków, Poland

Gonera, M., Wiewiórka, J., d'Obyrn, K., Bukowski, K., 2014. Wielician (Middle Badenian) foraminifers from the stratotype area - Wieliczka Salt Mine, Poland (Paratethys, Middle Miocene). Geological Quarterly, 58 (3): 427-438, doi: $10.7306 / \mathrm{gq} .1186$

The most abundant benthic foraminifers recorded in the Wielician salt-enclosed xenoliths are: Bulimina spp., Uvigerina spp., Valvulineria complanata, and Cibicides pseudoungerianus. The predominant taxon in the planktonic assemblage is Globigerina bulloides with a median $98.9 \%$ in biozone IIC and $89.1 \%$ in the later IID. The IIC assemblage differs from the IID one in both taxon composition and abundance. The most pronounced differences are those revealed by Valvulineria complanata counts, number of benthic taxa and the planktonic/benthic (P/B) ratio. Pseudotriplasia minuta (one of the Wielician index taxa) occurs only in the IID biozone, present in 16 among 28 samples. There is a noticeable difference in surface sculpture morphology pattern in the predominant Bulimina and Uvigerina taxa in the IIC versus the IID biozones. There are smooth (Bulimina elongata) and weakly striate (Uvigerina semiornata plexus) forms in the IIC biozone, followed by heavily costate (Bulimina striata) and spinose-pustulate (Uvigerina orbignyana plexus) forms in the IID. Globigerina druryi and G. decoraperta - the CPN 8 planktonic index taxa - had not been found in the material studied. Globigerinita uvula is unusually common in the samples studied. The samples analysed display an abundance of Globigerina bulloides typical of the sub-evaporite Wielician. Hence the studied Wielician stratotype area supports the thesis of the Globigerina bulloides Acme as the valid name designation for the substage.

Key words: Middle Miocene, Foraminifera, Wieliczka Salt Mine, Middle Badenian, Wielician

\section{INTRODUCTION}

The Wieliczka deposit belongs to the Central Paratethys Middle Miocene salinity crisis succession (Fig. 1 and Table 1). Evaporites of this age are present in the Carpathian Foredeep and the eastern part of the Intra-Carpathian Basin (Transylvanian Basin and its NE surroundings; Seneš, 1971; Steininger et al., 1985; Cicha et al., 1998; Peryt, 2006 with references therein). Across most of the Badenian evaporite basin, sulphate deposits accumulated and rock salt occurs only locally. In Poland, these sulphate and rock salt deposits are referred to as the Krzyżanowice and Wieliczka formations (Alexandrowicz et al., 1982; Garlicki, 1994) respectively. The name of the latter formation derives from the Wieliczka Salt Mine where rock salt has been mined since the 13th century (Fig. 2).

\section{* Corresponding author: gonera@iop.krakow.pl}

Received: March 4, 2014; accepted: July 16, 2014; first published online: August 19, 2014
The earliest description of foraminifers from Wieliczka Salt Mine was given by Reuss (1867). Foraminifers from the deposit were later investigated by Małecki (1954), Łuczkowska (1967, 1978a, 1985, 1995), Alexandrowicz (1975), Łuczkowska and Rolewicz (1990) and Gonera et al. (2012). These studies demonstrated that at this site, the foraminifer tests are redeposited. This is due to the complex geological history of the Wieliczka area, which is located at the border zone between the overthrusted Carpathians and the autochthonous Miocene formations of the Carpathian Foredeep (Fig. 1). Within the saliferous clay matrix (historically named Zuber) of the Salt Breccia Member (SBM), marly clay xenoliths of the sub-evaporite Badenian are moderately frequent (Gaweł, 1962). By contrast with the Zuber, the xenoliths bear foraminifers. Foraminifera of the IID assemblage (Table 1) are especially common in the xenoliths. Because of this, the IID assemblage was named the Wieliczka Assemblage by Alexandrowicz (1963).

Deposits of the Badenian salinity crisis interval are named the Wielician (Cicha et al., 1975; Papp et al., 1978b). The type section of this substage has been established in the northern part of the Rarańcza Gallery in Wieliczka Mine (Łuczkowska, 1978a; Figs. 2 and 3). The biostratigraphic markers of the Wielician are the FO of Globigerina druryi at the bottom and the 


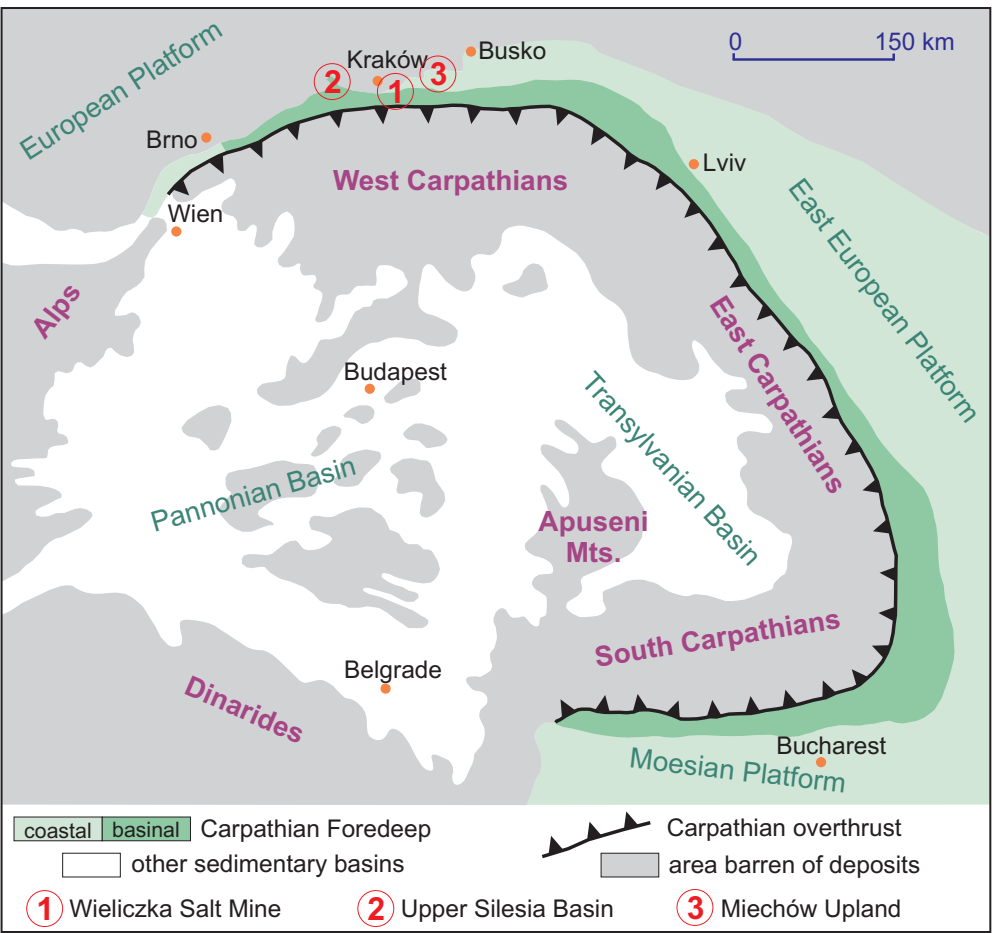

Fig. 1. Location of the Wieliczka deposit within the context of Central Paratethys marine sedimentation during the Badenian, after Seneš (1971) and Rögl (1998)

FO of Velapertina indigena at the top (Cicha et al., 1975; Papp, 1975). The Globigerina druryi-G. decoraperta Biozone has been accepted as the formal name of this biostratigraphic zone. It has been adopted despite objections regarding the biostratigraphic utility of $G$. druryi, G. decoraperta and $G$. aff. nepenthes made by Cicha et al. (1975: p. 23). During the Wielician the facies control on foraminifer content was very strong (Seneš, 1971; Cicha et al., 1998) and therefore other foraminifers are also used as Wielician indicators. The agglutinated Foraminifera Zone (Papp et al., 1978b), the Uvigerina costai Zone (Łuczkowska, 1964), the Pseudotriplasia Zone (Papp et al., 1978a) as well as the Globigerina bulloides Acme (Gonera, 1997) are among valid biostratigraphic markers of the substage.

The conspicuous environmental transformation at the Moravian/Wielician boundary has been interpreted as climatically driven (Szczechura, 1982; Filipescu, 2001; Gonera, 2001; Baldi, 2006). The turnover corresponds to the Middle Miocene Climate Optimum transition to the Middle Miocene Temperate Climate (Popescu and Brotea, 1994; Gonera et al., 2000; Bicchi et al., 2003; Harzhauser et al., 2011; Gonera and Bukowski, 2012; Gonera, 2013). Therefore, despite the shortcomings of the planktonic foraminiferal index taxa noted above, the Wielician lower boundary is very well established as regards the whole foraminiferal assemblage - its overall turnover at the bottom of this chronostratigraphic unit. Constraints do not occur on the upper biostratigraphic boundary of the Wielician, since its index taxon (the FO of Velapertina indigena) occurs relatively commonly in strata above the evaporites.

This paper provides taxonomic and quantitative analyses of the Wielician foraminifers from the stratotype place and compares the results with coeval autochthonous assemblages of the surrounding areas in the Carpathian Foredeep and also considers the stratigraphic utility of the Wielician index taxa. Ecological aspects of uvigerinas and buliminas occurring in the Wieliczka foraminifer assemblages are further discussed in a companion paper (in preparation) by the senior author.

\section{GEOLOGICAL SETTING}

The evaporites at Wieliczka include a number of diverse chloride facies (Gaweł, 1962; Wiewiórka, 1974, 1988). The main feature of the Wieliczka deposit is its bipartite structure (Fig. 2). In the two parts, different varieties of rock salt are found among siliciclastic deposits that are often sulphatebearing (Garlicki, 1994). The structural complexity of the deposit has been related to the regional geodynamic evolution (Oszczypko et al., 2006). In the lower (stratified) part of the Wieliczka deposit, strongly folded strata of various types of rock salt are found. They interfinger with various siliciclastic deposits. Foraminifera are only found here within the slump facies of the pre-evaporite Badenian (Łuczkowska and Rolewicz, 1990; Gonera et al., 2012). The upper (brecciated) part of the Wieliczka deposit is composed of a salty clay matrix (Zuber), comprising chaotically dispersed blocks of one type of salt only - referred to as Typical Green Salt (ZBT). In one of the mine locations situated within the higher brecciated part of the deposit, the Wielician stratotype was established (Łuczkowska, 1978a). It is also in this area that one finds the type locality of the Pseudotriplasia form (Małecki, 1954) - the agglutinated foraminifera taxon which serves as the index name of the Middle Badenian biozone (Papp et al., 1978a). The ZBT blocks vary in size (they range between 1 and over 100,000 cubic metres). Earlier studies have shown that the argillaceous marl xenoliths within the saliferous clay matrix represent sub-evaporite Badenian (Skawina Fm.) and are mostly composed of xenoliths containing Uvigerina costai Zone foraminifera (Alexandrowicz, 1975; Łuczkowska and Rolewicz, 1990).

\section{MATERIAL AND METHODS}

The xenoliths of the Skawina Fm. argillaceous marls from the brecciated part of the deposit were used as study material. Samples were collected at a number of sites of the Salt Breccia Member, from locations situated along the galleries and in chambers on the four upper levels of the Wieliczka Mine (Appendix $1^{*}$; Figs. 2 and 3 ). In an E-W direction, the distance between sampled sites was of approximately $2 \mathrm{~km}$. A total of 38 rock samples were collected from deposits lithologically analogous to those referred to the Wielician stratotype section by Łuczkowska (1978a). The rock samples were subject to the standard disaggregation procedure and then washed through a $0.1 \mathrm{~mm}$ sieve, the resulting residue (fraction $>0.1 \mathrm{~mm}$ ) being analysed stereomicroscopically. Foraminifera were taxonomically determined and their number in approximately $1 \mathrm{~cm}^{3}$ of residue was calculated. 


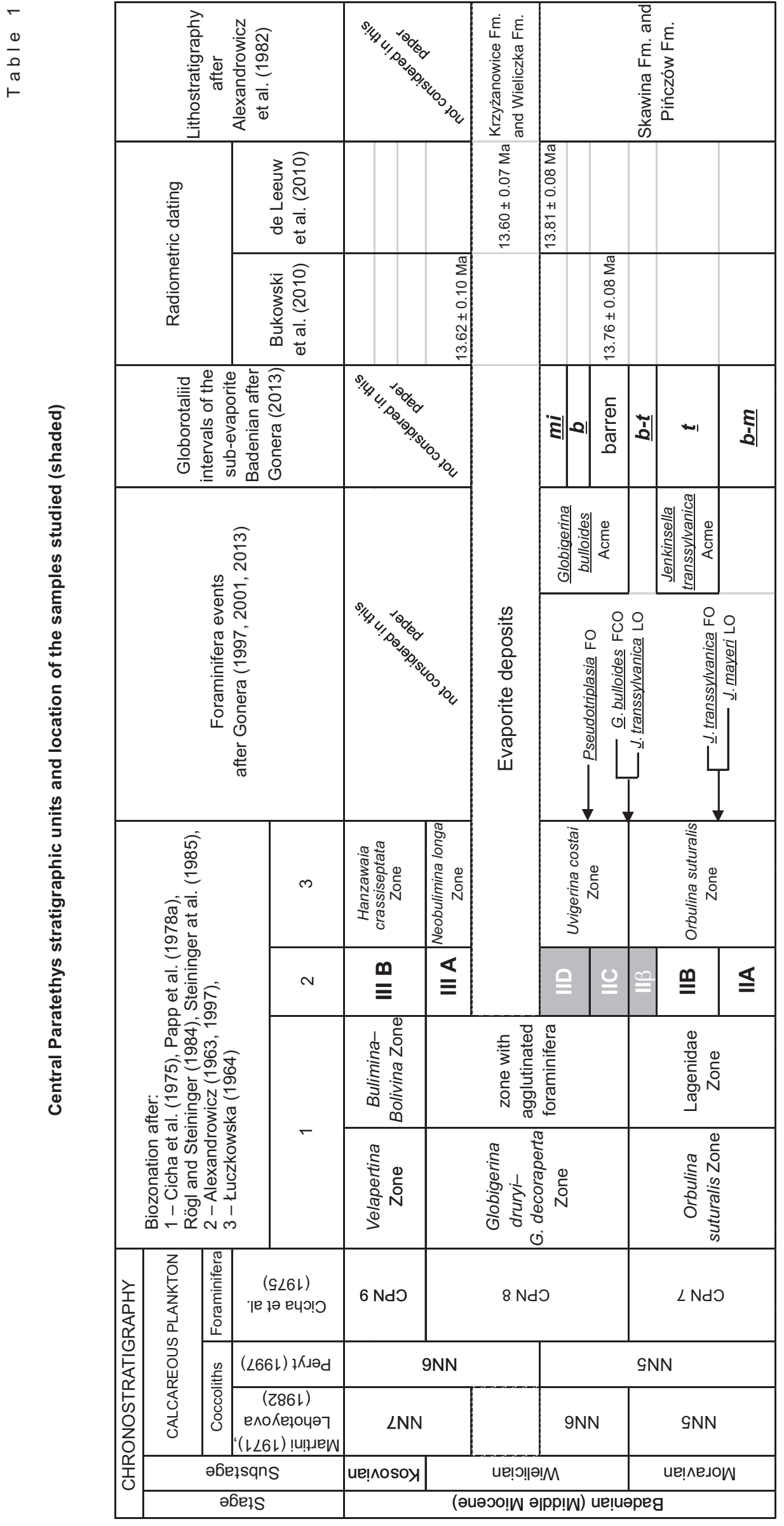


$\mathrm{m}$ a.s.l.

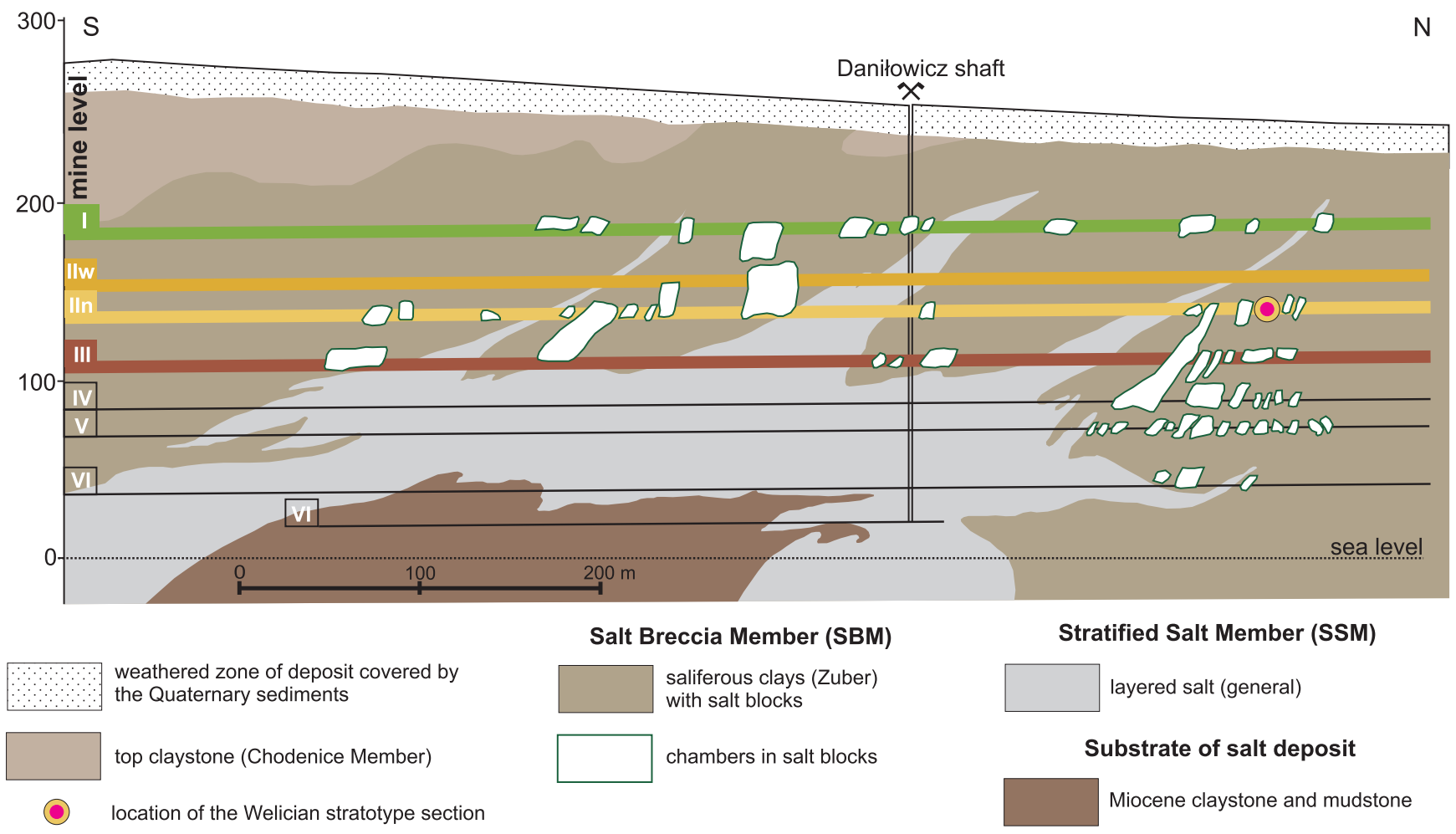

Fig. 2. Cross-section of the Wieliczka deposit (after Gawel, 1962)

Sampled Mine levels (I, IIw, IIn, III) are coloured

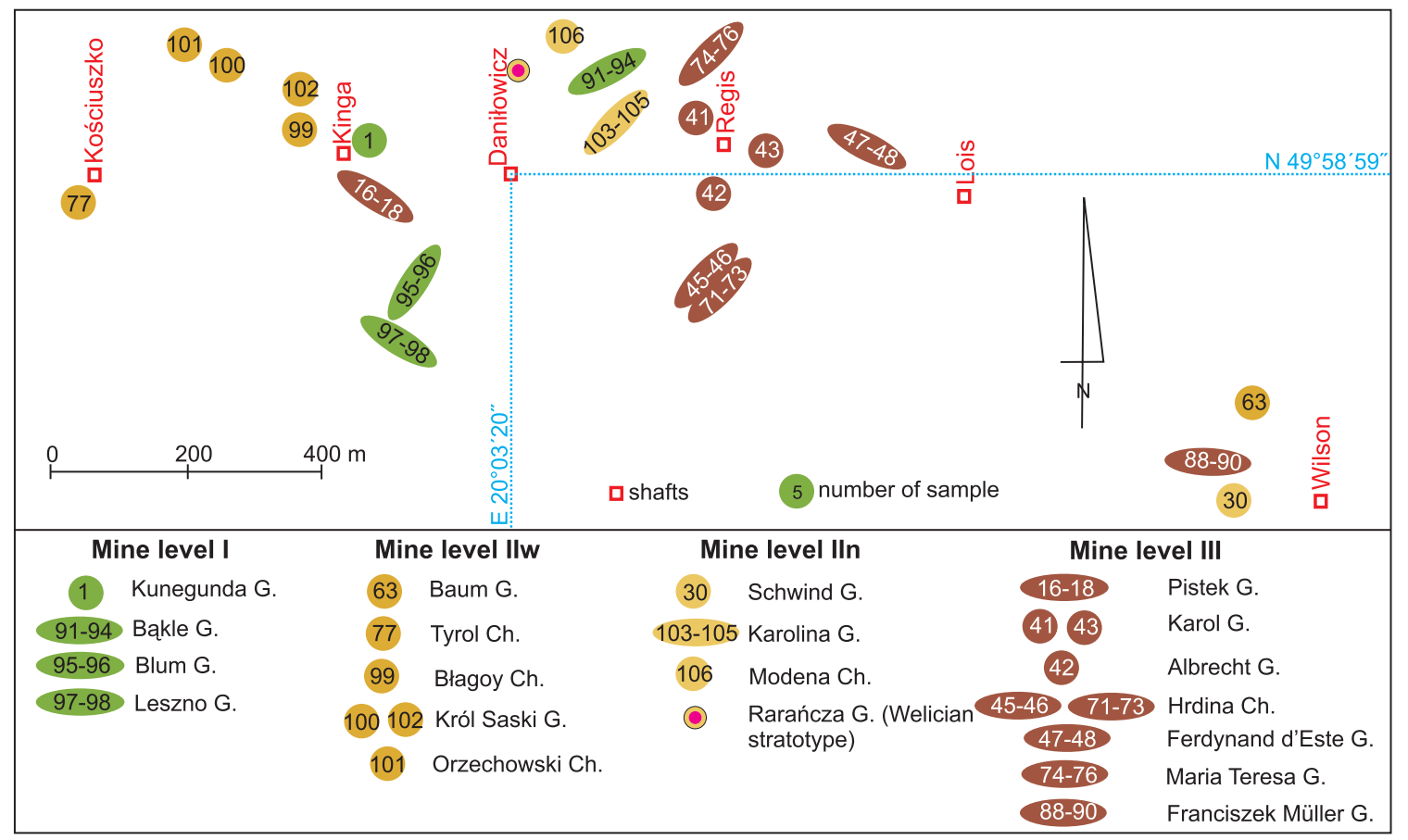

Fig. 3. Distribution of samples analysed in the Salt Breccia Member of the Wieliczka deposit

$$
\mathrm{G} \text { - gallery, Ch - chamber }
$$


Foraminiferal biozones proposed by Alexandrowicz (1963), planktonic index taxa (Cicha et al., 1975) and indicative globorotaliid presence (Gonera, 2013) were applied in the biostratigraphic analysis of the xenolith samples. In order to describe the taxonomic composition of the Wielician assemblages, the number of samples in which a given taxon occurs was used along with the standard quantitative data. In the material studied taxa present in at least a quarter of samples (i.e., in 8 of them) has been considered as widespread. Some taxa are rare (found in 5-7 samples) and others have an incidental status (they occur in only 1-4 samples).

Well-preserved tests of benthic (Uvigerina, Bulimina) and planktonic (Globigerinoides quadrilobatus, Globigerina bulloides, G. woodi) foraminifera were analysed for oxygen and carbon stable isotopes. The specimens filled by pyrite/evaporites were avoided during the selection. Therefore, it is assumed that the effects of infilling by these minerals on the stable isotope composition results obtained were negligible. This method was applied in the analysis of nine rock samples with the use of 24 weighed foraminiferal-test samples, which yielded the following pair of data: $\delta^{18} \mathrm{O}$ and $\delta^{13} \mathrm{C}$ for each weighed sample. The determination of the $\delta^{18} \mathrm{O}$ and $\delta^{13} \mathrm{C}$ was carried out in the GeoZentrum Nordbayern Laboratory of the Friedrich-Alexander-Universität in Erlangen-Nürnberg, Germany. All values are reported in per mil relative to $\mathrm{V}-\mathrm{PDB}$ by assigning a $\delta^{13} \mathrm{C}$ value of $+1.95 \%$ and a $\delta^{18} \mathrm{O}$ value of $-2.20 \%$ to NBS19. Reproducibility was checked by replicate analyses of laboratory standards and is better than $\pm 0.01-0.03 \%$.

\section{RESULTS}

\section{BIOSTRATIGRAPHY}

The biostratigraphy of the samples has been based on both indicative planktonic foraminifers and their assemblages shown in continuous sections through the Badenian (Alexandrowicz, 1963; Cicha et al., 1975; Brestenská, 1978; Gonera, 2013).

Following Cicha et al. (1975) and Brestenská (1978, with references therein), four of the samples analysed have a typically Moravian set of taxa (Appendix 1). The percentage of planktonic forms varies between $28.8 \%$ (sample 45 ) and $50.3 \%$ (sample 46); mean value $40.3 \pm 9.0 \%$ (median $41.0 \%$ ). The assemblage is dominated by Globoconella bykovae (mean value $25.4 \pm 24.0 \%$ ) and Globigerina bulloides (mean value $23.6 \pm$ $21.3 \%$ ). Common are Globigerinoides quadrilobatus (mean value $16.8 \pm 10.3 \%$ ), Orbulina suturalis (mean value $9.9 \pm$ $10.7 \%$ ) and Globoquadrina altispira (mean value $8.9 \pm 8.7 \%$ ). Jenkinsella transsylvanica is present in two samples having a mean value of $16.5 \pm 9.5 \%$. The following occur occasionally and in low percentages: Globigerina angustiumbilicata, Globigerina woodi, Turborotalita quinqueloba and Globigerinella obesa. On the basis of the globorotaliid assemblage, the samples can be appreciated as terminal Moravian - Globoconella bykovae and Jenkinsella transsylvanica interval i.e. $I I \beta$ biozone (Table 1).

The remaining 31 samples analysed are Wielician ones. Globigerina bulloides predominates among the planktonic foraminifers of these samples. The exceptions are three samples (42, 72 and 90), where Globigerina woodi predominates, and sample 1, where Turborotalita quinqueloba does. Planktonic forms are absent in sample 97 . The percentage of planktonic forms in the Wielician varies from $0.6 \%$ (sample 48 and 91 ) to $90.4 \%$ (sample 17). The mean value of planktonic foraminifers in Wielician xenoliths is $20.2 \%$ and it displays a very high standard deviation $(\sigma=20.4)$; median $15.0 \%$.

\section{TAXONOMIC DIVERSITY}

OF THE WIELICIAN FORAMINIFERS

The early and late Wielician assemblages (IIC and IID) recorded are shown in Appendix 1.

In the IIC samples studied, the percentage of planktonic specimens (the P/B ratio) varies from $6.0 \%$ (sample 18) to $90.4 \%$ (sample 17 ), having a mean value of $40.2 \pm 30.9 \%$ and a median of $37.4 \%$, which is similar to the Moravian samples of the material analysed (median 41.0\%). In the IIC plankton, practically only Globigerina bulloides is present (Table 2). The number of benthic taxa here is of 8-22 (median 15), which is considerably lower than in the Moravian ones, displaying 23-30 benthic taxa in the material studied (median 29).

There are two kinds of widespread taxa with either high or low percentages of benthic foraminifers. Widespread and frequent taxa of the IIC assemblage are: Bulimina elongata, Valvulineria complanata, Uvigerina semiornata, Cibicides pseudoungerianus and Nodosaria spp. A group of widespread taxa, but occurring in small amounts, is represented by: Melonis pompilioides, Globocassidulina crassa, Bolivina spp. and Spiroplectinella carinata (Table 2). The IIC assemblage includes exceptional taxa (present in 1-2 samples only), but reaching relatively high amounts: Caucasina schischinskyae (present in one sample only, but it attains $21.4 \%$ ), Pullenia bulloides (present in two samples only, with its share being 18.2 and $9.0 \%$ ), Bulimina pyrula (6.7\%) and Textularia gramen (3.5\%).

The remaining 28 Wielician samples (Appendix 1) are represented by assemblage IID. The percentage of planktonic specimens varies here from $0.0 \%$ to $64.4 \%$ (mean value $16 \pm 14.9 \%$ ) with a median of $14.4 \%$. Globigerina bulloides is present in 27 samples analysed. This is the most common planktonic foraminifer comprising a median $89.1 \%$ of Globigerinina. Rare types, but with meaningful percentages in some samples include: Globoconella bykovae (median 4.8\%), Globigerina woodi (median 10.3\%), Globigerina uvula (median 3.9\%), Globigerinoides quadrilobatus (median 5.1\%), Turborotalita quinqueloba (median 9.9\%). Exceptionally, Orbulina suturalis occurs (in three samples only, in one attaining $11.8 \%$ ).

Benthic foraminifers are taxonomically diverse in IID (Appendix 1). The number of taxa varies here from 14 (sample 89) to 35 (sample 99); the median is 25 taxa. The group of ubiquitous taxa within IID is composed of 31 taxa. Bulimina striata tests predominate with a median of $31.5 \%$. If the criterion of a median higher than $3.0 \%$ is adopted, nine consecutive taxa with a widespread status and meaningful percentages emerge from this set. These are (medians are given in brackets): Pseudotriplasia minuta (3.3\%), Nodosaria spp. (6.0\%), Cassidulina laevigata (3.2\%), Bulimina elongata (4.1), Uvigerina semiornata $(3.8 \%)$, Uvigerina orbignyana $(6.7 \%)$, Valvulineria complanata (4.6\%), Cibicides pseudoungerianus (6.4\%) and Pullenia bulloides (3.3\%).

The remaining 21 widespread taxa usually display low percentages (median less than $3 \%$ ), but occasionally create "percentage picks" (Appendix 1). These taxa are as follows (in brackets, high-percentage occurrences): Spiroplectinella carinata $(5.6 \%$ in sample 99$)$, Martinottiella communis $(19.0 \%$ in sam- 
Wielician foraminifera

\begin{tabular}{|c|c|c|c|c|c|}
\hline \multirow[b]{2}{*}{ Suborder } & \multirow[b]{2}{*}{ Taxons } & \multicolumn{2}{|c|}{$\mathrm{IIC}$} & \multicolumn{2}{|c|}{ IID } \\
\hline & & Average & $\begin{array}{l}\text { Standard } \\
\text { deviation }\end{array}$ & Average & $\begin{array}{l}\text { Standard } \\
\text { deviation }\end{array}$ \\
\hline \multirow{4}{*}{ Textulariina } & Spiroplectinella carinata & 1.6 & 1.4 & 1.4 & 1.3 \\
\hline & Pseudotriplasia minuta & & & 4.2 & 3.6 \\
\hline & Martinottiella communis & & & 1.9 & 5.2 \\
\hline & Textularia gramen & & & 1.7 & 2.4 \\
\hline \multirow{2}{*}{ Miliolina } & Spiroloculina badenensis & 1.3 & 0.6 & 0.6 & 0.4 \\
\hline & Hauerinidae $\left(^{*}\right)$ & 1.3 & 1.0 & 1.1 & 0.9 \\
\hline \multirow{5}{*}{ Lagenina } & Nodosaria spp. & 5.3 & 6.3 & 6.5 & 5.4 \\
\hline & Lenticulina inornata & 0.8 & 0.4 & 0.6 & 0.7 \\
\hline & Lagenidae & 0.5 & 0.3 & 0.7 & 0.6 \\
\hline & Guttulina communis & 0.4 & 0.2 & 0.3 & 0.1 \\
\hline & Ellipsolagenidae & 0.4 & 0.1 & 0.6 & 0.8 \\
\hline Robertinina & Hoeglundina elegans & & & 3.0 & 3.9 \\
\hline \multirow{19}{*}{ Rotaliina } & Bolivina spp. & 1.8 & 1.8 & 2.2 & 3.2 \\
\hline & Cassidulina laevigata & 1.4 & 1.4 & 7.4 & 8.7 \\
\hline & Globocassidulina crassa & 2.7 & 2.5 & 2.2 & 2.8 \\
\hline & Bulimina aculeata & 0.8 & 0.4 & 4.9 & 6.7 \\
\hline & Bulimina elongata & 39.8 & 29.7 & 12.0 & 16.9 \\
\hline & Bulimina pyrula & 2.7 & 3.5 & 1.0 & 1.3 \\
\hline & Bulimina striata & 1.4 & 1.5 & 30.6 & 14.2 \\
\hline & Uvigerina semiornata & 14.0 & 11.6 & 6.3 & 6.8 \\
\hline & Uvigerina orbignyana & & & 10.1 & 13.4 \\
\hline & Fursenkoina schreibersiana & 1.4 & 0.8 & 1.4 & 2.3 \\
\hline & Valvulineria complanata & 24.2 & 22.2 & 7.8 & 8.4 \\
\hline & Eponides repandus & & & 1.0 & 0.7 \\
\hline & Sphaeroidina bulloides & & & 3.5 & 3.5 \\
\hline & Cibicides pseudoungerianus & 7.8 & 6.4 & 7.3 & 3.4 \\
\hline & Asterigerinata planorbis & & & 0.3 & 0.1 \\
\hline & Melonis popmilioides & 3.3 & 3.5 & 2.7 & 2.4 \\
\hline & Pullenia bulloides & 13.6 & 6.5 & 4.5 & 4.0 \\
\hline & Heterolepa dutemplei & & & 1.4 & 1.9 \\
\hline & Elphidium spp. & & & 0.6 & 0.6 \\
\hline \multirow{5}{*}{ Globigerinina } & Globoconella bykovae & 0.7 & 0.5 & 10.9 & 13.4 \\
\hline & Globigerina bulloides & 97.6 & 3.3 & 75.7 & 31.0 \\
\hline & Globigerinita uvula & & & 6.9 & 7.4 \\
\hline & Globigerinoides quadrilobatus & 3.3 & 1.6 & 8.5 & 9.0 \\
\hline & Turborotalita quinqueloba & 1.7 & 0.6 & 17.6 & 23.5 \\
\hline
\end{tabular}

* - Siphonaperta mediterranensis, Quinqueloculina akneriana, Pyrgo simplex, Triloculina gibba; quantitative data on the widespread taxa (i.e. those occurring in at least 3 of the samples analysed)

ple 1), Textularia gramen (9.2\% in sample 98), Spiroloculina badenensis, Hauerinidae, Lenticulina inornata, Lagenidae, Guttulina communis, Ellipsolagenidae (3.9\% in sample 42$)$, Hoeglundina elegans (14.2\% in sample 76$)$, Bolivina spp. (10.7\% in sample 102), Globocassidulina crassa (8.8\% in sample 47), Bulimina aculeata (30.9\% in sample 89 ), Bulimina pyrula (5.1\% in sample 71 ), Fursenkoina schreibersiana (9.5\% in sample 1), Eponides repandus, Sphaeroidina bulloides $(12.6 \%$ in sample 94), Asterigerinata planorbis, Melonis pompilioides $(10.6 \%$ in sample 77$)$, Heterolepa dutemplei $(7.4 \%$ in sample $100)$ and Elphidium spp. Rare and low-percentage taxa of the IID samples are: Reophax variloculus, Frondicularia annularis,
Glandulina ovula, Reusella pulchra, Caucasina schischinskyae, Neoconorbina terquemi and Allomorphina trigona. Hansenisca soldanii also belongs among the rare taxa, even though it represents $8.8 \%$ in one case (sample 71 ).

The following are present sporadically in the IID biozone: Dendrophrya latissima, Karreriella gaudryinoides, Dimorphina variabilis, Uvigerina acuminata, Gavelinopsis nanus, Glabratellidae, Eoeponidella linki, Nonion fabum and Ammonia beccarii. Apart from Nonion fabum and Karreriella gaudryinoides, which amount to 3.7 and $1.7 \%$ respectively, all of these taxa represent less than $1.0 \%$. 


\section{COMPARISON AND DISCUSSION}

A comparison of the foraminifera studied with Wielician foraminifers elsewhere poses the following problems: (1) morphologically similar taxa are sometimes given different names by researchers, (2) non-uniform measurement data is usually provided as regards quantitative assessment of the taxa (estimated semiquantitative or only noting the presence of the forms of the taxon compared).

Already in the pioneering study of the Wieliczka deposits foraminifera by Reuss (1867) and revised by Łuczkowska (1967), an analogy was demonstrated between the taxonomic composition of the Wieliczka Salt Mine foraminifera and "those of the Upper Tegel" and "Leitha Limestones" located in the Vienna Basin. The age of the Wieliczka deposits was thus assigned by Reuss (1867) to the Middle Miocene. The Rhabdogonium minutum taxon described in Reuss's (1867) study was examined by Małecki (1954) on the basis of specimens from the archival xenolith sample from the Hrdina Chamber. This analysis showed that this is a new genus of agglutinated foraminifera, which was named Pseudotriplasia (Małecki, 1954). Further studies of Paratethys Middle Miocene stratigraphy supported its utility as a Wielician index taxon (e.g., Papp et al., 1978a).

Pseudotriplasia has been found in many xenolith sites in the Salt Breccia Member (Łuczkowska and Rolewicz, 1990). The taxon is present within the Wielician stratotype section in the Rarańcza Gallery (Łuczkowska, 1978a). It has been also found in Wielician silty marls incorporated in the Miocene-flysch slump deposits at the southern border of the Wieliczka deposit (Alexandrowicz, 1975). The taxon is also common in the slump facies within the Stratified Salt Member (Gonera et al., 2012). The Hrdina Chamber is still a topotypical site for Pseudotriplasia, but the taxon - like many others (Appendix 1) - occurs irregularly within Wielician xenoliths. As it happens, it does not occur in any of the presently examined Wielician samples in this chamber (samples 71, 72 and 73). This taxon is classified in the widespread and noticeable percentage category (see above chapter) and it is present in 16 out of 28 the IID samples examined, attaining up to $13.1 \%$ in one of them. By comparison, Pseudotriplasia has been observed in 2/3 of IID biozone analysed samples in the Upper Silesia Basin, having a mean value of $8.5 \pm 10.5 \%$ of benthic foraminifers (Gonera, 2001). Pseudotriplasia is apparently absent in the early Wielician samples (IIC in Appendix 1). Although Pseudotriplasia is absent also from certain late Wielician samples (IID in Appendix 1), other foraminiferal assemblage features indicate a conspicuous difference between IIC and IID.

In the western part of the Carpathian Foredeep, IIC is also defined as the level of Valvulineria complanata (Cicha, 1957) or of an assemblage with Globigerina bulloides and Valvulineria complanata (Łuczkowska, 1958). Given its taxonomic composition, it is a transitional assemblage between the "Lanzendorf fauna" (cf. Grill, 1941) and the Wieliczka assemblage (IID). This late Wielician biozone was also named the Bulimina Bed (Kirchner, 1956), Uvigerina asperula-Bulimina striata-Pseudotriplasia (Cicha, 1957), Uvigerina asperula (Pishvanova, 1969; cf. Filipescu, 2001) and Uvigerina costai (Kuczkowska, 1963, 1964).

Valvulineria complanata ranges in Paratethys from the Lower Miocene to the end of the Badenian (Cicha et al., 1998). Due to environmental reasons it is frequent in the IIC biozone of the Wielician - a highly oligotaxic, r-selected set of Badenian assemblages (Gonera, 2001, 2013). Valvulineria complanata as an IIC biozone index taxon is present in the IIC samples ex- amined in amounts of 5.8-62.7\% (median 18.6\%) with the number of benthic taxa of 8-22 (median 15) and a P/B ratio of 6.0-90.4\% (median 37.4\%). In the IID biozone samples examined, those indicators are noticeably different and are respectively: 1.7-36.3\% (median 4.6\%), 14-35 (median 24) and $0.0-64.4 \%$ (median $14.4 \%$ ). Apart from those, the characteristic feature of the IIC assemblage is the unquestioned quantitative dominance of Bulimina elongata and Uvigerina semiornata among the benthic foraminifera (Table 2). These features of IIC as an early Wielician biozone have been observed in numerous profiles of the Carpathian Foredeep Badenian in the Wieliczka surroundings. In the Kłaj-1 borehole, the Badenian faciostratotype section in Poland, IIC occurs in a manner analogous to that of the Wieliczka deposits (Łuczkowska, 1978b). The IIC assemblage lateral extent is from the Upper Silesia Basin (Alexandrowicz, 1963; Gonera, 2001) through the Kraków Bold (Alexandrowicz, 1964) to the east of this structure (Kirchner, 1956; Łuczkowska, 1958, 1963). Assemblage IIC also occurs in the northern rim of the Carpathian Foredeep, from the Działoszyce Trough in the Miechów Upland (Alexandrowicz, 1965; Szczechura, 2000) to the stratotype area of both the Pińczów and Krzyżanowice Formations near Busko (Alexandrowicz and Parachoniak, 1956). In the Wola Zagojska section, the IIC type assemblage of foraminifers is located $8 \mathrm{~m}$ below the gypsum, within the marly clays enriched with crystals of gypsum (sample number 3 in Alexandrowicz and Parachoniak, 1956). Its foraminifers display a scarcity of taxa, and foraminifer tests compare to both the lower and the upper part of this section - features typical of IIC. In the sample discussed, only infrequent tests of Bulimina elongata, Pullenia bulloides, Sphaeroidina bulloides, Uvigerina cf. semiornata and single Globigerina bulloides among planktonic forms were found. IIC is easily identified in the deposits eastward of this area (Łuczkowska, 1964); nevertheless, the assemblage in the area is barren of Valvulineria and has been included by Łuczkowska (1964) either into the Uvigerina costai Zone (Młyny 1 and Budy 1 boreholes) or both the Orbulina suturalis and the Uvigerina costai Zones (Grabki Duże N8 borehole).

Bulimina and Uvigerina prevail among a number of benthic foraminifer tests of the Wielician studied (Table 2). They contain first of all Bulimina elongata with Uvigerina semiornata (IIC assemblage) and also Bulimina striata with Uvigerina orbignyana (IID assemblage). This is also the case with Wielician foraminifers of the SSM xenoliths in the Wieliczka deposit (Gonera et al., 2012).

Bulimina and Uvigerina also dominate in the Wielician deposits of the Kłaj-1 borehole (Kirchner, 1956; Łuczkowska, 1978b). This borehole contains a complete succession of the Wielician foraminifer biozones, i.e., IIC followed by IID. Following Kirchner (1956), they are referred to as the Valvulineria Bed and the Bulimina Bed, respectively. Bulimina buchiana d'Orbigny and Uvigerina tenuistriata Reuss with $U$. asperula Czjzek are the dominant taxa in the younger bed (cf. Kirchner, 1956). These two Wielician assemblages in the Kłaj-1 borehole were regarded by Łuczkowska (1978b) as one stratigraphic unit (Level E) named the Uvigerina costai Said Zone in the Badenian faciostratotype (Łuczkowska, 1978b). In her description of the buliminas and uvigerinas of Level $E$ the following are listed: Bulimina elongata, B. gibba Fornasini, B. gutsulica Livental, $B$. striata and Uvigerina hispida Schwager, U. brunensis Karrerr, U. pudica Łuczkowska (Łuczkowska, 1978b). The same Wielician foraminifer succession was observed in the Wielician between Wieliczka and Bochnia (Łuczkowska, 1958).

West of Wieliczka, on the Kraków Bold, the Wielician foraminifers are present within autochthonous Badenian deposits (Alexandrowicz, 1964). The IIC interval in these deposits 
displays scarce tests of Globigerina bulloides and Valvulineria complanata. Buliminas and uvigerinas are not present in the area. On the other hand, the IID interval of this area comprises a taxonomically rich and abundant assemblage with Globigerina bulloides and Pseudotriplasia with numerous Bulimina striata, Uvigerina asperula and $U$. brunensis.

West of the Kraków Bold, in the Upper Silesia Basin, the Wielician foraminifers have been described in numerous boreholes (Alexandrowicz, 1963; Gonera, 1997, 2001). Buliminas and uvigerinas are widespread and common there, and they show both taxonomic and quantitative differences between IIC and IID assemblages (Gonera, 2001). Buliminas attain up to $54.4 \%$ of the Wielician benthic foraminifers with a mean value of $6.4 \pm 9.5 \%$; their share is $11.7 \pm 12.4 \%$ in $\mathrm{IIC}$, and $5.4 \pm 8.5 \%$ in IID. Taxa in significant numbers in these biostratigraphic zones of the Wielician include: B. elongata, B. gibba, B. pyrula and $B$. striata in IIC and $B$. striata in IID. The content of Wielician uvigerinas in this area reaches $90.2 \%$, with a mean value of $12.6 \pm 17.3 \%$. Although present only in half of the IIC samples analysed, the uvigerinas display relatively high counts (mean value $27.0 \pm 18.2 \%$ ). $U$. semiornata is mainly observed (mean value $33.0 \pm 20.0 \%$ ). Uvigerinas are present in each IID sample, displaying a mean value of $11.6 \pm 17.0 \%$. This younger Wielician assemblage consists mainly of $U$. orbignyana (mean value $15.6 \pm 20.7 \%$ ), U. venusta Franzenau (mean value $15.5 \pm$ $15.4 \%$ ) and $U$. semiornata (mean value $10.2 \pm 15.2 \%$ ).

The Wielician foraminifers from the coastal, northern, part of the Carpathian Foredeep sedimentary area were first described by Alexandrowicz and Parachoniak (1956) in the Wola Zagojska section noted above - the ongoing type area of the Krzyżanowice Formation. Bulimina elongata with Uvigerina hosiusi Ten Dam and Reinhold, U. striata (d'Orbigny) and $U$. hovei Garrett were observed in the lower Wielician deposits (sample 3 already mentioned) of the section whereas in its upper part (cf. IID assemblage), Bulimina striata with Uvigerina asperula, U. hosiusi, U. rutilla Cushman and Todd were found (Alexandrowicz and Parachoniak, 1956).

Eastwards of the Wola Zagojska section, an Uvigerina costai Zone type area is found (Łuczkowska, 1963, 1964; Peryt, 2013 with references therein). The biozone comprises IIC and IID type assemblages (Łuczkowska, 1978b, 1998). Both buliminas and uvigerinas are widespread (Łuczkowska, 1964). Bulimina elongata, B. gibba, B. gutsulica and Uvigerina costai are common in the early Wielician (cf. IIC) of this area. Buliminas that predominate in the upper section (cf. IID) are the Bulimina striata, accompanied by $B$. elongata and $B$. gibba. The IID uvigerinas of this locality include Uvigerina pudica, U. brunensis, U. hispida, U. hovei and U. costata Bieda (Łuczkowska, 1964).

Wielician foraminifers were also described at some locations in the Miechów Upland westwards of the Wola Zagojska section. The full profile of the sub-evaporite Wielician were penetrated by the Działoszyce borehole (Alexandrowicz, 1965). The older layer is composed of Bulimina elongata and Uvigerina hosiusi, together with Valvulineria complanata and Globigerina bulloides typical of the IIC. The younger Wielician assemblage (IID) consists of Bulimina striata and Uvigerina asperula with $U$. brunensis (Alexandrowicz, 1965). In the area of the sulphur deposit near Posądza, Bulimina elongata and Uvigerina peregrina Cushman group were found in the older layer (Szczechura, 2000) followed by Bulimina cf. costata d'Orbigny with Uvigerina pudica and U. costai (OdrzywolskaBieńkowa, 1964; Szczechura, 2000). Near Racławice the Wielician foraminifers comprise Bulimina elongata and Bulimina gibba with common Uvigerina pygmoides Papp and Turnovsky, U. hispida and U. costai (Gonera and Kulka, 1979).

Isotope data on Bulimina and Uvigerina demonstrate that the two taxa have similar contents of $\delta^{18} \mathrm{O}$ (Gonera and
Bukowski, 2012). Therefore, the mean value is used here for the two as an indicator of the content of the isotope in benthic foraminifers (Fig. 4). In the samples studied, this value corresponds well with the values of this isotope for the Wielician in the other analysed parts of the Polish Carpathian Foredeep (Table 3). The data are too limited to conclude if the Globigerina woodi $\delta^{13} \mathrm{C}$ found (Fig. 4) has any interspecific meaning considered for instance by Chaproniere (1988).

The $\delta^{13} \mathrm{C}$ of late Wielician benthic foraminifers (biozone IID) has negative values. This is the opposite to that of the early Wielician biozone (IIC), which displays positive $\delta^{13} \mathrm{C}$ values (Gonera and Bukowski, 2012). Also within planktonic foraminifera tests there is noticable drop at the IIC/IID boundary (Table 3). Usually the change from positive to negative $\delta^{13} \mathrm{C}$ signifies a pronounced increase in organic carbon in the environment (Berger et al., 1981). Most probably, this increase in the Wielician samples has resulted from the enhancement in productivity and extensive water eutrophication. The onset of such a process at the IIC/IID boundary and its continuation up to the evaporite sedimentation has also been interpreted using palaeoecological methods (Gonera, 2001; Peryt, 2013). It is also the case in the Wielician xenoliths studied from the Salt Breccia Member of the Wieliczka deposit. If the noticeable foraminiferal $\delta^{13} \mathrm{C}$ transition from positive to negative values at the IIC/IID boundary was not controlled by local causes it may be correlated with the similar, globally recorded $\delta^{13} \mathrm{C}$ event known as the termination of the "Monterey" carbon-isotope excursion (Berger et al., 1981).

In the early Wielician, IIC biozone, Globigerina bulloides is practically the only planktonic foraminifer in the samples studied (Appendix 1; Table 2). This is the case regardless of whether planktonic forms comprise 6.0 or $90.4 \%$ of the total foraminifers (sample 18 and 17 respectively). The taxon is predominant also

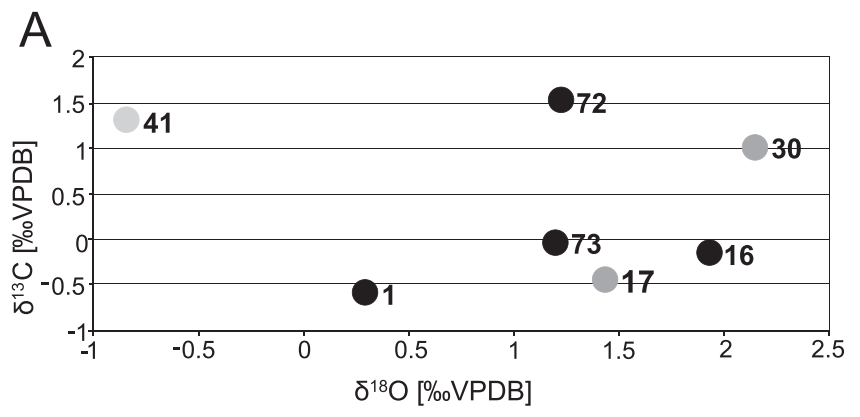

B

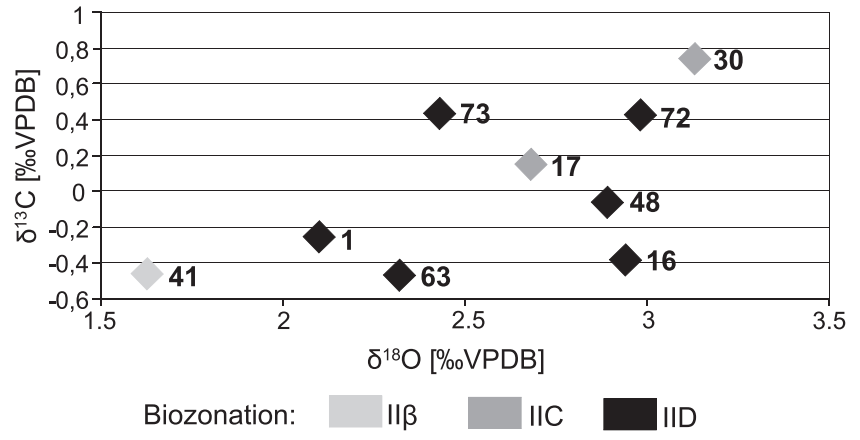

Fig. 4. Plot of foraminiferal oxygen and carbon isotope values of the xenolith samples from the Salt Breccia Member

A - planktonic (Globigerinoides quadrilobatus in sample 41, Globigerina woodi in sample 72 and Globigerina bulloides in the others), B - benthic (Bulimina spp. and Uvigerina spp. mean value) 
Foraminiferal isotopic composition of the Wielician biozones

\begin{tabular}{|c|c|c|c|c|c|c|}
\hline \multirow{2}{*}{ LOCALITY } & \multicolumn{2}{|c|}{$\delta^{18} \mathrm{O}[\% \circ \mathrm{V}-\mathrm{PDB}]$} & \multicolumn{2}{|c|}{$\delta^{13} \mathrm{C}[\% \circ \mathrm{V}-\mathrm{PDB}]$} & \multirow{2}{*}{ Biostratigraphy } & \multirow{2}{*}{ References } \\
\hline & PLANKTONIC & BENTHIC & PLANKTONIC & BENTHIC & & \\
\hline \multirow{2}{*}{$\begin{array}{l}\text { Wieliczka, Salt } \\
\text { Breccia Member }\end{array}$} & $1.45 \pm 0.42$ & $2.61 \pm 0.38$ & $0.19 \pm 0.92$ & $-0.05 \pm 0.40$ & IID & \multirow{2}{*}{ present paper } \\
\hline & $1.79 \pm 0.50$ & $2.91 \pm 0.32$ & $0.29 \pm 1.02$ & $0.45 \pm 0.42$ & IIC & \\
\hline \multirow{2}{*}{$\begin{array}{l}\text { Wieliczka, Green } \\
\text { Stratified Salt IV }\end{array}$} & $2.27 \pm 0.24$ & $2.84 \pm 0.22$ & $0.35 \pm 0.43$ & $-0.32 \pm 0.30$ & IID & \multirow{2}{*}{ Gonera et al. (2012) } \\
\hline & $2.25 \pm 0.18$ & $3.06 \pm 0.24$ & $1.30 \pm 0.37$ & $0.33 \pm 0.36$ & IIC & \\
\hline \multirow{3}{*}{ Upper Silesia Basin } & $1.88 \pm 0.19$ & $2.54 \pm 0.27$ & $0.29 \pm 0.40$ & $-0.42 \pm 0.46$ & IID & \multirow{2}{*}{$\begin{array}{c}\text { Gonera and Bukowski } \\
(2012)\end{array}$} \\
\hline & $1.28 \pm 1.11$ & $2.06 \pm 0.72$ & $0.53 \pm 0.28$ & $0.07 \pm 0.11$ & IIC & \\
\hline & $1.95 \pm 0.40$ & $2.26 \pm 0.42$ & $1.08 \pm 1.33$ & $-0.02 \pm 0.42$ & $\begin{array}{c}\text { Uvigerina costai } \\
\text { Zone }\end{array}$ & $\begin{array}{c}\text { Durakiewicz et al. (1997); } \\
\text { Gonera et al. (2000) }\end{array}$ \\
\hline Busko area & $0.77 \pm 0.95$ & $1.99 \pm 0.64$ & $0.15 \pm 0.49$ & $-0.31 \pm 0.43$ & $\begin{array}{l}\text { Uvigerina costai } \\
\text { Zone }\end{array}$ & Peryt (2013) \\
\hline
\end{tabular}

in the IID samples, having a median value of $89.1 \%$. Common Globigerina bulloides tests persist throughout this upper Wielician interval; however, additional Globigerinina also occur in the samples (Appendix 1). This is also the case described by Łuczkowska and Rolewicz (1990) and Gonera et al. (2012) for many others Wielician xenoliths of the Wieliczka deposit.

Globigerina bulloides ranges in Central Paratethys from the Karpatian (Lower Miocene) to the end of the Badenian (Cicha et al., 1998). The taxon predominates in sub-evaporite Wielician in autochthonous deposits eastwards of Wieliczka, including the Badenian faciostratotype section Kłaj-1 noted above (Kirchner, 1956; Łuczkowska, 1958, 1978b). The same is true of the planktonic foraminifera in the Kraków Bold - although Globigerina bulloides occurs here in a small number of specimens only (Alexandrowicz, 1964, 1973). The Wielician strata of the Upper Silesia Basin bear abundant Globigerina bulloides among planktonic foraminifers; the percentage of this taxon in IIC is $99.3 \pm 1.5 \%$ and $76.7 \pm 31.7 \%$ in the IID biozone (Alexandrowicz, 1963; Gonera, 2001; Gonera et al., 2003). Wielician deposits in the Wola Zagojska section yield a small number of $G$. bulloides as the only planktonic foraminifers in the older layer, accompanied by rare Globigerinoides trilobus in the younger one (Alexandrowicz and Parachoniak, 1956). There is a similar set of planktonic foraminifers in the Kraków Bold Wielician deposits. On the other hand, Globigerina bulloides is common and prevails in sub-evaporite Wielician planktonic foraminifers both in the type area of the Uvigerina costai Zone (Łuczkowska, 1964) and the Krzyżanowice Fm. stratotype area (Peryt and Gedl, 2010; Peryt, 2013). The same is true of the sub-evaporite Wielician strata of the Miechów Upland (Alexandrowicz, 1965; Gonera and Kulka, 1979; Szczechura, 2000). The examples presented above concern the areas surrounding Wieliczka, but the same abundance and almost exclusiveness of $G$. bulloides in sub-evaporite Wielician occurs from the Ukrainian part of the Carpathian Foredeep (Serova, 1955), the Czech part of this structure (Cicha, 1957; Doláková et al., 2014 with references therein) and theTransylvanian Basin (Filipescu, 2001 with references therein). This is also the case in the areas where Wielician evaporites have not accumulated. A good example of this is provided by the Badenian faciostratotypes in the Danube Lowland Basin: above the taxonomically diverse CPN 7 planktonic assemblage, G. bulloides of CPN 8 occurs in abundance (Brestenská, 1978). This is also the case in the Slovak part of the Vienna Basin (Kováčová and Hudáčková, 2009).

Recent Globigerina bulloides occurs predominantly in high-latitude regions, but is commonly encountered within upwelling areas and boundary currents in low-latitude regions (Bé, 1977; Boltovskoy et al., 1996). Its abundance is connected with cooler and high nutrient supply areas. This probably was the case in the sub-evaporite Wielician. Enhanced nutrient supply during this time span appeared due to the climate cooling and vertical extending of the surface mixed layer within an anti-estuarine regime (Gonera, 2001, 2013) or during upwelling (Key et al., 2013). In some of the Wielician samples studied Turborotalita quinqueloba and Globigerinita uvula are also frequent (Appendix 1). Such an assemblages is indigenous for contemporary subantarctic and transitional zones of oceans (Bé and Hutson, 1977; Boltovskoy et al., 1996).

Summing up, the sub-evaporite Wielician is composed of dominant Globigerina bulloides among the planktonic foraminifers. The other taxa are present at most occasionally and in minor amounts in the Wielician strata. This can justify the use of the Globigerina bulloides Acme as the title for the sub-evaporite Wielician planktonic foraminifer biozone (Gonera, 1997). This seems justified in the sense that both currently used terms, Globigerina druryi and G. decoraperta as index taxa pose difficulties in application. This is due the extreme rarity of their occurrence in the Wielician strata. Furthermore, the second of these taxa is used to refer to tropical-subtropical foraminifers following Kennett and Srinivasan (1983). Its presence in the Wielician strata may be problematic due to temperature-related conditions in the Paratethys area concerned. As interpreted based on foraminiferal palaeoecology this was a climate cooling interval connected with the Mi3 global event (Gonera, 2001). This is also seen in foraminiferal oxygen and carbon isotopes (Table 3; Peryt, 2013 with references therein) and supported by radiometric data (de Leeuw et al., 2010).

In order to ensure the documentation at least in terms of formal stratigraphy, a register of appropriate sites would be recommended, created at the Wieliczka Salt Mine (Wiewiórka et al., 1994). Needs in this regard include:

- a hypostratotype section of the Wielician (as the primary designated Wielician stratotype, in the Rarańcza Gallery, is barely accessible at present and should be complemented by substitute stations;

- a reference section of IID with Pseudotriplasia;

- the entire biostratigraphic documentation of the Wielician;

- documentation of a wide range of the lithological variation of the Wieliczka Fm. as the halite facies of the Wielician evaporites. 


\section{CONCLUSIONS}

1. Bulimina spp., Uvigerina spp., Valvulineria complanata and Cibicides pseudoungerianus among benthic and Globigerina bulloides among planktonic foraminifera are the representative and the most abundant foraminifers of the Wielician xenoliths in the stratotype area. The occurrence of Pseudotriplasia is restricted to the late Wielician (IID biozone).

2. A difference is observed between the Bulimina and Uvigerina taxa predominance in the early (IIC) versus the late (IID) Wielician. In general, the $B$. elongata and U. semiornata d'Orbigny plexus (Appendix 2) are found by comparision with the $B$. striata and $U$. orbignyana Czjzek plexus (Appendix 2). This constitutes a noticeable difference between the early Wielician assemblage (IIC) and the late assemblage (IID). This pronounced difference lies in the morphology of the surface sculpture within both buliminas and uvigerinas - the two most common taxa of the Wielician substage. In the IIC assemblage, smooth buliminas and weakly striate ornamented uvigerinas dominate as opposed to the IID assemblage, in which buliminas and uvigerinas tests have rich heavy costae, spinose and pustulose ornamentation. The difference appears because of regional changes in environment.
3. Globigerina bulloides predominates in the planktonic foraminifers of both the IIC and IID biozones. In IID, it is accompanied by sporadic occurrence of low-percentage Globigerinoides, Orbulina and Globoconella bykovae. Wielician Globigerinina at a stratotypical site contains a surprisingly large amount of Globigerinita uvula tests. So far, the index taxa planktonic foraminifera - Globigerina druryi and Globigerina decoraperta, have not been traced in the material examined.

4. The early Wielician assemblage (IIC) is poorly represented or absent in thin successions of the substage - this is in particular the case in the coastal areas of the Carpathian Foredeep. This is not the case of the Wieliczka deposit xenoliths. The source area of the Wielician xenoliths studied contains a complete set of the Wielician biozone (IIC and IID). Sub-evaporite Wielician foraminifers in the area occur in a taxonomic composition typical of the basinal part of the Carpathian Foredeep.

Acknowledgements. The authors would like to thank the reviewers S. Filipescu, N. Hudáčková, and one anonymous one for comments that helped improve the manuscript. The isotopic analyses have been financed by the research Project AGH No. 11.11.140.320. granted by the Polish Ministry of Sciences and Higher Education to K. Bukowski.

\section{REFERENCES}

Alexandrowicz, S.W., 1963. Stratigraphy of the Miocene deposits in the Upper Silesian basin (in Polish with English summary). Prace Instytutu Geologicznego, 39.

Alexandrowicz, S.W., 1964. Stratygrafia mikropaleontologiczna iłów mioceńskich na obszarze Krakowa (in Polish). Sprawozdania z Posiedzeń Komisji Naukowych PAN, Oddział w Krakowie, 8: 274-277.

Alexandrowicz, S.W., 1965. Das stratigraphische Profil des Untertortons in Działoszyce und sein Verhältnis zur Aufteilung des Miozäns im Wiener Becken. Bulletin of the Polish Academy of Sciences, Earth Sciences, 13: 73-80.

Alexandrowicz, S.W., 1973. Profil wzorcowy warstw skawińskich (badenian) w Skawinie koło Krakowa (in Polish). Sprawozdania z Posiedzeń Komisji Naukowych PAN, Oddział w Krakowie, 16: 194-195.

Alexandrowicz, S.W., 1975. Pozycja stratygraficzna utworów mioceńskich z poprzeczni Kunegunda w kopalni Wieliczka. Sprawozdania z Posiedzeń Komisji Naukowych PAN, Oddział w Krakowie, 18: 510-513.

Alexandrowicz, S.W., 1997. Lithostratigraphy of the Miocene deposits in the Gliwice area (Upper Silesia, Poland). Bulletin of the Polish Academy of Sciences, Earth Sciences, 45: 167-179.

Alexandrowicz, S.W., Parachoniak, W., 1956. Miocene tuffites in the vicinity of Pińczów on the Nida river (in Polish with English summary). Acta Geologica Polonica, 6: 301-326.

Alexandrowicz, S.W., Garlicki, A., Rutkowski, J., 1982. Podstawowe jednostki litostratygraficzne miocenu zapadliska przedkarpackiego (in Polish). Kwartalnik Geologiczny, 26 (2): 470-471.

Baldi, K., 2006. Paleoceanography and climate of the Badenian (Middle Miocene, 16.4-13.0 Ma) in the central Paratethys based on foraminifera and stable isotope $\left(\delta^{18} \mathrm{O}\right.$ and $\left.\delta^{13} \mathrm{C}\right)$ evidence. International Journal of Earth Sciences (Geologische Rundschau), 95: 119-142.

Bé, A.W.H., 1977. An ecological, zoogeographic and taxonomic review of recent planktonic foraminifera. In: Oceanic Micro- paleontology (ed. A.T.S. Ramsay): 1-100. Academic Press, London.

Bé, A.W.H., Hutson, W.H., 1977. Ecology of planktonic foraminifera and biogeographic patterns of life and fossil assemblages in the Indian Ocean. Micropaleontology, 23: 369-414.

Berger, W.H., Vincent, E., Thiersten, H.R., 1981. The deep-sea record: major steps in Cenozoic ocean evolution. SEPM Special Publication, 32: 489-504

Bicchi, E., Ferrero, E., Gonera, M., 2003. Paleoclimatic interpretation based on Middle Miocene planktonic foraminifera: the Silesia Basin (Paratethys) and Monferrato (Tethys) record. Palaeogeography, Palaeoclimatology, Palaeoecology, 196: 265-303.

Brestenská, E., 1978. Faziostratotypen des Badenian. In: Chronostratigraphie und Neostratotypen: Miozän der Zentralen Paratethys (ed. E. Brestenská): 175-188. Bd VI. M4 Badenian (Moravien, Wielicien, Kosovien). VEDA SAV, Bratislava.

Boltovskoy, E., Boltovskoy, D., Correa, N., Brandini, F., 1996. Planktonic foraminifera from the southwestern $\left(30^{\circ}-60^{\circ} \mathrm{S}\right)$ : Species-specific patterns in the upper $50 \mathrm{~m}$. Marine Micropaleontology, 28: 53-72.

Bukowski, K., de Leeuw, A., Gonera, M., Kuiper, K.F., Krzywiec, P., Peryt, D., 2010. Badenian tuffite levels within the Carpathian orogenic front (Gdów-Bochnia area, Southern Poland): radioisotopic dating and stratigraphic position. Geological Quarterly, 54 (4): 449-464.

Chaproniere, G.C.H., 1988. Globigerina woodi from the late Oligocene and early Miocene of Southeastern Australia. Journal of Foraminiferal Research, 18: 124-129.

Cicha, I., 1957. Zpráva o mikrobiostratigrafických výzkumech neogénu v ostravské oblasti (in Czech). Zprávy o geologických výzkumach v roce, $1957: 20-22$

Cicha, I., Čtyroká, J., Jiřiček, R., Zapletalová, I., 1975. Principal biozones of the Late Tertiary in East Alps and West Carpathians. In: Biozonal division of the Upper Tertiary basins of the Eastern Alps and West Carpathians, IUGS Proceedings of the VI. Congress, Bratislava (ed. I. Cicha): 19-34. 
Cicha, I., Rögl, F., Rupp, Ch., Čtyroká, J., 1998. Oligocene-Miocene foraminifera of the Central Paratethys. Abhandlungen der Senckenbergischen Naturforschenden Gesellschaft, 549.

de Leeuw, A., Bukowski, K., Krijgsman, W., Kuiper, K.F., 2010. Age of the Badenian salinity crisis; impact of Miocene climate variability on the circum-Mediterranean region. Geology, 38: 715-718.

Doláková, N., Holcová, K., Nehyba, S., Hladilová, S., Brzobohatý, R., Zágoršek, K., Hrabovský, J., Seko, M., Utescher, T., 2014. The Badenian parastratotype at Židlochovice from the perspective of the multiproxy study. Neues Jahrbuch für Geologie und Paläontologie - Abhandlungen, 271: 169-201.

Durakiewicz, T., Gonera, M., Peryt, T.M., 1997. Oxygen and carbon isotopic changes in the Middle Miocene (Badenian) foraminifera of the Gliwice area (SW Poland). Bulletin of the Polish Academy of Sciences, Earth Sciences, 45: 145-156.

Filipescu, S., 2001. Wielician foraminifera at the western border of the Transylvanian Basin. Studia Universitatis Babeş-Bolyai, Geologia, 46: 115-123.

Garlicki, A., 1979. Sedimentation of Miocene salts in Poland (in Polish with English summary). Prace Geologiczne, 119.

Garlicki, A., 1994. Formal lithostratigraphic units of the Miocene: Wieliczka Formation (in Polish). Przegląd Geologiczny, 42: 26-28.

Gaweł, A., 1962. The geological structure of the Wieliczka salt deposit (in Polish with English summary). Prace Instytutu Geologicznego, 30: 305-331.

Gonera, M., 1997. Miocene foraminiferal assemblages in the Gliwice area (Upper Silesia, Poland). Bulletin of the Polish Academy of Sciences, Earth Sciences, 45: 97-105.

Gonera, M., 2001. Foraminiferida and paleoenvironment of the Badenian formations (Middle Miocene) in the Upper Silesia (Poland) (in Polish with English summary). Studia Naturae, 48.

Gonera, M., 2013. Globorotaliid intervals of the sub-evaporite Badenian (Middle Miocene) in the Upper Silesia Basin (Central Paratethys, Poland). Geological Quarterly, 57 (4): 757-767.

Gonera, M., Bukowski, K., 2012. Isotopic events in the Early/Middle Badenian (Miocene) of the Upper Silesia Basin (Central Paratethys). Geological Quarterly, 56 (3): 561-568.

Gonera, M., Kulka, A., 1979. The age and stratigraphic position of the Heterostegina Sands, Miechów and Racławice Region (in Polish with English summary). Zeszyty naukowe AGH, Geologia, 5: 65-71.

Gonera, M., Peryt, T.M., Durakiewicz, T., 2000. Biostratigraphical and paleoenvironmental implications of isotopic studies $\left({ }^{18} \mathrm{O}\right.$, ${ }^{13} \mathrm{C}$ ) of the middle Miocene (Badenian) foraminifers in the Central Paratethys. Terra Nova, 12: 231-238.

Gonera, M., Peryt, T.M., Durakiewicz, T., 2003. Coiling direction in Globigerina bulloides of Middle Miocene age. Journal of Micropaleontology, 22: 141-146.

Gonera, M., Bukowski, K., d’Obyrn, K., Wiewiórka, J., 2012. Foraminifera in slump deposits of the Badenian (Middle Miocene) Green Stratified Salt in Wieliczka, Poland. Geological Quarterly, 56 (4): 869-880.

Grill, R., 1941. Stratigraphische Untersuchungen mit Hilfe von Mikrofaunen in Wiener Becken. Oel und Kohle, 37: 595-602.

Harzhauser, M., Piller, W.E., Müllegger, S., Grunert, P., Micheels, A., 2011. Changing seasonality patterns in Central Europe from Miocene Climate Optimum to Miocene Transition deduced from the Crassostrea isotope archive. Global and Planetary Change, 76: 166-169.

Kennett, J.P., Srinivasan, M.S., 1983. Neogene Planktonic Foraminifera. A Phylogenetic Atlas. Hutchinson Ross Publishing Company. Stroudsburg.

Key, M.M. Jr., Zágoršek, K., Patterson, W.P., 2013. Paleoenvironmental reconstruction of the Early to Middle Miocene Central Paratethys using stable isotopes from bryozoan skeletons. International Journal of Earth Sciences, 102: 305-318.

Kirchner, Z., 1956. Miocene stratigraphy of the Central Carpathian Foreland based on microfaunal studies (in Polish with English summary). Acta Geologica Polonica, 6: 421-449.
Kováčová, P., Hudáčková, N., 2009. Late Badenian foraminifers from the Vienna Basin (Central Paratethys): stable isotope study and paleoecological implications. Geologica Carpathica, 60: 59-70.

Krézsek, C., Bally, A.W., 2006. The Transylvanian Basin (Romania) and its relation to the Carpathians Fold and Thrust Belt: insights in gravitational salt tectonic. Marine and Petroleum Geology, 23: 405-442.

Lehotayova, R., 1982. Miocene nannoplankton zones in West Carpathians. Zapadne Karpaty Seria Paleontologia, 8: 91-100.

Loeblich, A.P., Jr., Tappan, H., 1988. Foraminiferal Genera and their Classification. Van Nostrand Reinhold, New York.

Łuczkowska, E., 1958. The Miocene microfauna of the Carpathian Foredeep (in Polish with English summary). Kwartalnik Geologiczny, 2 (1): 105-125.

Łuczkowska, E., 1963. Foraminiferal zones in the Miocene, south of the Holy Cross Mts. Bulletin of the Polish Academy of Sciences, Earth Sciences, 11: 29-34.

Łuczkowska, E., 1964. The micropaleontological stratigraphy of the Miocene in the region of Tarnobrzeg-Chmielnik (in Polish with English summary). Prace Geologiczne, 20.

Łuczkowska, E., 1967. Remarks on Foraminifer described from the Miocene of Wieliczka by A.E. Reuss in 1867. Biuletyn Instytutu Geologicznego, 211: 328-336.

Łuczkowska, E., 1978a. Holostratotypen der Understufen des Badenia. Wielician. In: Chronostratigraphie und Neostratotypen: Miozän der Zentralen Paratethys. Bd. VI. M4 Badenian. Veda, Bratislava (ed. E. Brestenská): 148-151.

Łuczkowska, E., 1978b. Faziostratotypen des Badenian. Bohrung Kłaj-1. In: Chronostratigraphie und Neostratotypen: Miozän der Zentralen Paratethys. Bd. VI. M4 Badenian. Veda, Bratislava (ed. E. Brestenská): 155-158.

Łuczkowska, E., 1985. Biostratygrafia miocenu z wierceń H-1 i H-5 w Wieliczce (in Polish). Sprawozdania z Posiedzeń Komisji Naukowych PAN, Oddział w Krakowie, 29: 310-312.

Łuczkowska, E., 1995. Korelacja biostratygraficzna miocenu z nowych wierceń w Wieliczce (in Polish). Zeszyty Naukowe AGH, Geologia, 21: 255-265.

Łuczkowska, E., 1998. Marine Miocene deposits of the Paratethys in Poland. Abhandlungen Senckenbergischen Naturforschenden Gesellschaft, 549: 29-34.

Łuczkowska, E., Rolewicz, J., 1990. Comparison between assemblages from the stratified salt member and salt breccia member from Wieliczka (in Polish with English summary). Annales Societatis Geologorum Poloniae, 60: 149-168.

Małecki, J., 1954. New genera of agglutinated foraminiferal from the Polish Miocene (in Polish with English summary). Rocznik Polskiego Towarzystwa Geologicznego, 22: 497-505.

Martini, E., 1971. Standard Tertiary and Quaternary Calcareous Nannoplankton Zonation. Proceedings of the II Planktonic Conference, Rome, 1970, 2: 739-785.

Odrzywolska-Bieńkowa, E., 1964. Miocen w rejonie Posądzy w świetle badań mikropaleontologicznych (in Polish). Kwartalnik Geologiczny, 8 (4): 902-903.

Oszczypko, N., Krzywiec, P., Popadyuk, I., Peryt, T., 2006. Carpathian Foredeep Basin (Poland and Ukraine): its sedimentary, structural, and geodynamic evolution. AAPG Memoir, 84: 293-350.

Papp, A., 1975. Grundlagen der biostratigraphischen Gliederung im Neogen der Zentralen Paratethys. Proceedings of the VIth Congress RCMNS Bratislava, September 4-7, 1975, 1: 111-112.

Papp, A., Cicha, I., Seneš, J., 1978a. Gliederung des Badenian, Faunenzonen und Unterstufen. In: Chronostratigraphie und Neostratotypen: Miozän der Zentralen Paratethys. Bd. VI. M4 Badenian (Moravien, Wielicien, Kosovien). VEDA SAV, Bratislava (ed. E. Brestenská): 49-52.

Papp, A., Rögl, F., Cicha, I., Čtyroká, J., Pishvanova, L.S., 1978b. Planktonische Foraminiferen im Badenian. In: Chronostratigraphie und Neostratotypen. Miozän der Zentralen Paratethys. Bd. VI. M4 Badenian (Moravien, Wielicien, Kosovien). VEDA SAV, Bratislava (ed. E. Brestenská): 268-278. 
Peryt, D., 1997. Calcareous nannoplankton stratigraphy of the Middle Miocene in the Gliwice area (Upper Silesia, Poland). Bulletin of the Polish Academy of Sciences, Earth Sciences, 45: 119-131.

Peryt, D., 2013. Foraminiferal record of the Middle Miocene climate transition prior to the Badenian salinity crisis in the Polish Carpathians Foredeep basin (Central Paratethys). Geological Quarterly, 57 (1): 141-164.

Peryt, D., Gedl, P., 2010. Palaeoenvironmental changes preceding the Middle Miocene Badenian salinity crisis in the northern Polish Carpathian Foredeep Basin (Borków quarry) inferred from foraminifers and dinoflagellate cysts. Geological Quarterly, 54 (4): 487-508.

Peryt, T.M., 2006. The beginning, development and termination of the Middle Miocene Badenian salinity crisis in Central Paratethys. Sedimentary Geology, 188-189: 379-396.

Pishvanova, L.S., 1969. Stratigraphical and facial distribution of foraminifera in Miocene deposits of the western part of Ukrainian SSR. Rocznik Polskiego Towarzystwa Geologicznego, 39: 335-350.

Popescu, Gh., Brotea, D., 1994. Evolution of the Transylvanian foraminiferal assemblages during Late Oligocene and Middle Miocene. The Miocene from the Transylvanian Basin, Romania. Editura Carpatica Cluj-Napoca: 119-124.

Reuss, A.E., 1867. Die fossile Fauna der Steinsalzablagerung von Wieliczka in Galizien. Sitzungsberichte der Kaiserlichen Akademie der Wissenschaften in Wien, Mathematisch-Naturwissenschaftliche Class, 55: 17-182.

Rögl, F., 1998. Palaeogeographic considerations for Mediterranean and Paratethys seaways (Oligocene to Miocene). Annalen des Naturhistorischen Museums in Wien, 99A: 279-310.
Rögl, F., Steininger, F.F., 1984. Neogene Paratethys, Mediterranean and Indo-Pacific Seaways. In: Fossils and Climate (ed. P. Branchley): 171-200, Wiley.

Seneš, J., 1971. Korrelation des Miozans der Zentralen Paratethys (Stand 1970). Geologicky Zbornik, 22: 3-9.

Serova, Y., 1955. Stratigrafiya i fauna foraminifer miotsenovikh otlozheniy Predkarpatya. Materialy po biostratigrafii zapadnykh oblastey Ukrainskoy SSR. Moskva, Ministerstvo Geologii i Okhrany Nedr: 261-458.

Steininger, F.F., Seneš, J., Kleeman, K., Rögl, F., eds., 1985. Neogene of the Mediterranean Tethys and Paratethys. Stratigraphic correlation tables and sediment distribution maps. Univ. Vienna Inst. Paleont.

Szczechura, J., 1982. Middle Miocene foraminiferal biochronology and ecology of SE Poland. Acta Paleontologica Polonica, 27: 125-130.

Szczechura, J., 2000. Palaeoenvironments of the Middle Miocene evaporite-bearing deposits from the Działoszyce Trough, Carpathian Foredeep, Poland, based on microfaunal studies. Geological Quarterly, 44 (2): 119-135.

Wiewiórka, J., 1974. Poziomy najstarszej soli kamiennej w pokładowym złożu solnym Wieliczki. Studia i Materiały do Dziejów Żup Solnych w Polsce, 3: 46-58.

Wiewiórka, J., 1988. Warunki geologiczne eksploatacji soli w Żupach Krakowskich. In: Dzieje Żup Krakowskich. Muzeum Żup Krakowskich, Wieliczka: 37-70.

Wiewiórka, J., Gonera, M., Kuc, T., Brudnik, K., 1994. Geological documentary sites in the Wieliczka Salt Mine (in Polish with English summary). Chrońmy Przyrodę Ojczysta, 50: 57-65. 